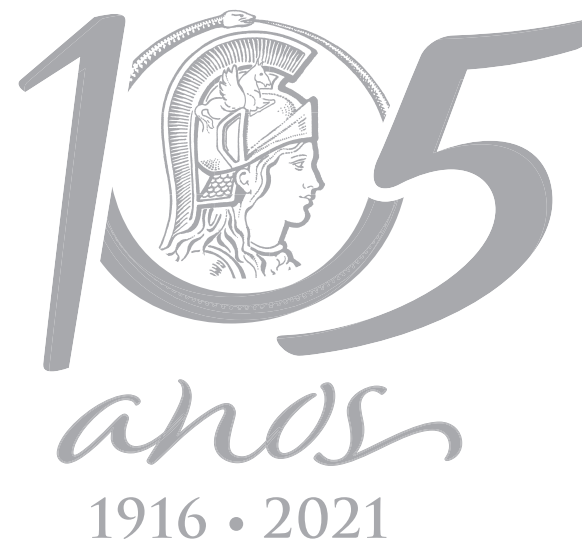

$1916 \cdot 2021$

\title{
Essential oil of Mentha suaveolens Ehrh., composition and antibacterial activity against bacterial fish pathogens
}

\author{
SECIL METIN, BEHIRE I. DIDINEN, ISA TELCI \& OZNUR DILER
}

\begin{abstract}
In this study, it was determinated the essential oil of cultivated apple mint, Mentha suaveolens Ehrh. composition and in vitro antibacterial activity of against 11 fish pathogen bacteria including Gram-positive (Staphylococcus warneri, Staphylococcus sp., Lactococcus garvieae, Vagococus salmoninarum) and Gram-negative (Aeromonas hydrophila, Aeromonas sobria Aeromonas cavieae, Vibrio anguillarum, Pseudomonas aeroginosa, Yersinia ruckeri, Edwardsiella tarda) by using agar diffusion assay. The main component of $M$. suaveolence oil was obtained as piperitenone oxide. The essential oil exhibited strong inhibitory activity such as inhibition zone sizes: $30-50 \mathrm{~mm}$ at 250-1000 $\mathrm{\mu L}$ $\mathrm{mL}^{-1}$ concentrations against $V$. anguillarum; $16-20 \mathrm{~mm}^{2}$ at $31.25-125 \mu \mathrm{L} \mathrm{mL}^{-1}$ concentrations

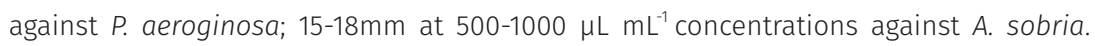
However, it was found to be moderately effective against E. tarda (8-15 mm), Y. ruckeri (9-12mm), S. warneri (9-10mm), V. salmoninarum (9mm) and Staphylococcus sp. (8-9mm). The essential oil showed weak inhibitory activity against A. cavieae (5-8), A. hydrophila (6-7mm), L. garvieae (5-7mm). Thus, effect of essential oil of M. suaveolens on immune response and disease resistance against Vibrio anguillarum, A. sobria and P. aeroginosa should be investigated in vivo in cultured fish species in future studies.
\end{abstract}

Key words: Mentha suaveolens, essential oil, bacterial fish pathogens, in vitro antibacterial effect.

\section{INTRODUCTION}

In aquaculture, antimicrobial agents are widely used to preventfish diseases caused by infectious agents. It is known that the unconscious use of antimicrobial agents in the treatment of fish diseases causes many negative effects on environment, fish and human health (Schnick et al. 1997). Therefore, the use of herbal products to control of fish pathogens in aquaculture is an alternative and current practice.

Phytochemicals such as phenolics, polysaccharides, proteoglycans and flavonoids may play a role in preventing or controlling infectious pathogens (Citarasu 2010). Many essential oils and plant extracts have been studied and shown to be effective against fish pathogens (Abutbul et al. 2005, Bansemir et al. 2006, Ekici et al. 2011, Haniffa \& Kavitha 2012, Al Laham \& Al Fadel 2014, Ontas et al. 2016, Diler et al. 2017, Metin et al. 2017). These compounds may constitute alternative prophylactic and therapeutic agents in aquaculture because of their antibacterial properties (Turker \& Yıldırım 2015).

Mentha, a genus of the Lamiaceae family, is represented by about 31 species and 13 natural hybrids, mainly perennial herbs, growing wildly in damp or wet places throughout Europe, Asia, Africa, Australia and North America (Kumar et al. 2011). Mints are fast growing, invasive and generally tolerate a wide range of agro-climatic 
conditions (Božović et al. 2015). The most common and popular mints for cultivation are peppermint (M. piperita), spearmint (Mentha spicata) and apple mint ( $M$. suaveolens) (Chauhan \& Agarwal 2013). Mentha suaveolens is an aromatic herb and has a spearmint flavor, which is used in the Mediterranean areas in the traditional medicine. It has an extensive range of biological activities, including cytotoxic, antimicrobial, antioxidant, anti-inflammatory, hypotensive, analgesic, sedative and insecticidal properties (Moreno et al. 2002, El-Kashoury et al. 2014, Božović et al. 2015).

The essential oil of $M$. suaveolens includes piperitone oxide and piperitenone oxide as major components. Other chemotypes of this species showed high percentage of alcohols (menthol) or ketones (pulegone, piperitenone and dihydrocarvone) (Oumzil et al. 2002, Sutour et al. 2008, El-Kashoury et al. 2014, Božović et al. 2015).

There are a few studies on chemical the antibacterial and anti-fungal effects of $M$. suaveolens (Oumzil et al. 2002, Sutour et al. 2008, El-Kashoury et al. 2014, Božović et al. 2015). Antibacterial effects of ethanolic extract and fractions of $M$. suaveolens against human pathogenic bacteria Staphylococcus aureus (ATCC12600), Streptococcus faecalis (ATCC19433), Bacillus subtilis (ATCC6051), Escherichia coli (ATCC11775), Neisseria gonorrhoeae (ATCC19424), Pseudomonas aeruginosa (ATCC10145) (ElKashoury et al. 2014) and major components of Mentha suaveolens essential oils against Staphylococcus aureus, Staphylococcus simulans, Staphylococcus saprophyticus, Enterococcus sp., Bacillus anthracis, Escherichia coli, Klebsiella pneumoniae, Pseudomonas aeruginosa, Pseudomonas fluorescens, Proteus mirabilis, Enterobacter avium, Citrobacter freundii (Oumzil et al. 2002) has been reported in the previous studies. Moreover, there is no study on antimicrobial activity of $M$. suaveolens against fish pathogens. Thus, in this study was identified the major constituents of essential oil of $M$. suaveolens and investigated antibacterial effects against fish pathogens.

\section{MATERIALS AND METHODS}

\section{Plant material}

Essential oil of "apple mint", a variety of Mentha suaveolence Ehrh., was used in the research. Cuttings from rhizomes of the cultivar were planted in experimental pilots of TARUM in Isparta University of Applied Sciences. Fertilizer was applied after planting at the rate of $50 \mathrm{~kg}$ $\mathrm{ha}^{-1}$ nitrogen, and $50 \mathrm{~kg} \mathrm{ha-1} \mathrm{P}_{2} \mathrm{O}_{5}$. Plots were watered with drip irrigation system and kept weed free by hand hoeing. Plants were harvested at floral initiation (in mid-July). Fresh material after harvest was dried at 35으 in drier cabin for essential oil distillation.

\section{Preparation of essential oil}

The essential oil was obtained with the distillation process using a Clevenger apparatus. Distilled water $(2000 \mathrm{~mL})$ was used for the distillation of dried plant samples (100 g). Distillation time was approximately $2 \mathrm{~h}$ at boiling point. The oil phase was separated and stored in dark glass bottle at $4^{\circ} \mathrm{C}$ in fridge until both antibacterial studies and Gas chromatography-mass spectroscopy (GC-MS) analysis.

\section{Gas chromatography-mass spectroscopy analysis of the essential oil}

The GC-MS TIC (total ion chromatogram) analysis was performed using a Hewlett-Packard 6890 series gas chromatograph (Perkin Elmer (PE) Auto System XL, USA), fitted with a flame ionization detector (FID). The PE Auto System $\mathrm{XL}$ gas chromatograph was employed under the following conditions: capillary column, CPWax 
52CB (50 m x $0.32 \mathrm{~mm}$; film thickness $1 / 40.25 \mathrm{Im}$ ); oven temperature programmed, $60-220^{\circ} \mathrm{C}$ raised at a rate of $2{ }^{\circ} \mathrm{C} \mathrm{min}-1$ and then held at $220^{\circ} \mathrm{C}$ for $20 \mathrm{~min}$; injector and detector temperatures, $240^{\circ} \mathrm{C}$; carrier gas, helium at flow rate of $40 \mathrm{~mL}$ $\mathrm{min}^{-1}$; and split ratio, $1 / 20 \mathrm{~mL} \mathrm{~min}^{-1}$. Relative percentage amounts were calculated from chromatograms by the Turbo Crom Navigator computer program (Baydar et al. 2004).

\section{In vitro antibacterial activity}

Fish pathogen bacteria were obtained from the culture collection in Isparta University of Applied Sciences, Microbiology Laboratory of Fisheries Faculty. Bacteria strains; Staphylococcus warneri, Staphylococcus sp., Lactococcus garvieae, vagococus salmoninarum, vibrio anguillarum from rainbow trout; Aeromonas sobria from yellow tail cichlid; Aeromonas hydrophila ATCC 7966, Aeromonas cavieae ATCC 15468, Pseudomonas aeroginosa ATCC27953, Yersinia ruckeri, Edwardsiella tarda DSMZ 300052 were used in the test.

Agar disc diffusion method was performed for the antibacterial screening of the essential oil of M. suaveolens Ehrh. For the test, bacteria were grown in Tryptic Soy Broth for $24 \mathrm{~h}$ at 25 ${ }^{\circ} \mathrm{C}$ and then $100 \mu \mathrm{L}$ of each culture transferred into $100 \mathrm{~mL}$ cooled (to $45^{\circ} \mathrm{C}$ ) Tryptic Soy Agar. After solidifying and drying for 15-20 minute, wells were punched (diameter $=3 \mathrm{~mm}$ ) and 25 $\mu \mathrm{L}$ of different concentrations prepared with 96\% ethanol (the test concentrations: 1000, 500, $250,125,62.5,31.25 \mathrm{\mu L} \mathrm{mL}^{-1}$ ) added to wells in triplicates. Controls were prepared using $96 \%$ ethanol. Plates were incubated at $25^{\circ} \mathrm{C}$ for $24 \mathrm{~h}$ and observed for clearing zones around the wells (Andrews 2004). The antibacterial activity of plant extracts was interp reted as proposed by Bansemir et al. (2006). Inhibition zones $>15 \mathrm{~mm}$ were categorized as strong activity, from 8 to 15 $\mathrm{mm}$ as moderate activity, and from 1 to $8 \mathrm{~mm}$ as weak activity.

\section{RESULTS AND DISCUSSION}

M. suaveolens essential oil include piperitone oxide and piperitenone oxide as major components (Božović et al. 2015). Other chemotypes of this species showed high percentage of alcohols (menthol) or ketones (pulegone, piperitenone and dihydrocarvone) (Oumzil et al. 2002, Sutour et al. 2008, El-Kashoury et al. 2014, Božović et al. 2015). In the present study, the chemical composition of $M$. suaveolence essential oil was characterized by one hundred different components and were determined 10 volatile constituents, representing $87.68 \%$ of the total composition (Table I). The main component of $M$. suaveolence oil was piperitenone oxide (66.23\%).

The antimicrobial activities of the essential oil of M. suaveolence against fish pathogens were represented in Table II. The essential oil exhibited strong inhibitory activity against V. anguillarum (30-50 mm) at 250-1000 $\mu \mathrm{L}$ $\mathrm{mL}^{-1}$ concentrations against; $P$. aeroginosa

Table I. Major chemical constituents of essential oil of the Mentha suaveolence.

\begin{tabular}{|c|c|c|}
\hline Components & R. Time & Area \% \\
\hline Piperitenone oxide & 31.409 & 66.23 \\
\hline Germacrene-d & 38.078 & 5.48 \\
\hline Limonene & 10.366 & 3.63 \\
\hline 1 Octen 3YL Actate & 14.542 & 2.75 \\
\hline Ledene & 44.855 & 2.38 \\
\hline $\begin{array}{c}\text { 2-Cyclopenten-1-one, 3-methyl } \\
\text { - 2-(2-pentenyl)-, (Z)- }\end{array}$ & 32.724 & 1.83 \\
\hline Farmesene<(E),beta-> & 36.570 & 1.60 \\
\hline cis-Ocimene & 10.665 & 1.34 \\
\hline 2-Beta- Pinene & 8.106 & 1.27 \\
\hline Beta-Myrcene & 8.546 & 1.17 \\
\hline & & \\
\hline & & \\
\hline
\end{tabular}


(16-20mm) at 31.25-125 $\mu \mathrm{L} \mathrm{mL}^{-1}$ concentrations against; $A$. sobria (15-18mm) at 500-1000 $\mathrm{L} \mathrm{m} \mathrm{mL}^{-1}$ concentrations. In addition, the essential oil was found to be moderately effective against E.tarda (8-15 $\mathrm{mm}$ at all concentrations), Y. ruckeri (9$12 \mathrm{~mm}$ at $\left.125-1000 \mu \mathrm{L} \mathrm{mL}^{-1}\right)$, S. warneri (9-10mm at 125-1000 $\left.\mathrm{LL} \mathrm{mL}^{-1}\right), \mathrm{V}$. salmoninarum ( $9 \mathrm{~mm}$ at 250 and $500 \mu \mathrm{L} \mathrm{mL}^{-1}$ ), Staphylococcus sp. (8-9mm at 250-1000 $\mathrm{L} \mathrm{mL}^{-1}$ ) in the present study. Similarly, in the previous studies noted Mentha piperita essential oil had moderate effect against $Y$. ruckeri and V. salmoninarum (Adel et al. 2016, Metin et al. 2017).

In the present study, M. suaveolence essential oil showed weak inhibitory activity against $A$. hydrophila. In contrast, Birinci Yıldırım \& Türker (2018) noted strong antibacterial activity of $M$. piperita against $A$. hydrophila.

\section{CONCLUSION}

In conclusion, it was found that the main component of $M$. suaveolence essential oil was piperitenone oxide (66.23\%) in this study. M. suaveolence essential oil exhibited strong antibacterial effect against $V$. anguillarum (30-50mm), P. aeroginosa (16-20mm), A. sobria (15-18mm); moderately antibacterial effect against E.tarda (8-15 mm), Y. ruckeri (9$12 \mathrm{~mm})$, S. warneri $(9-10 \mathrm{~mm})$, V. salmoninarum (9mm), Staphylococcus sp. (8-9mm) and weak antibacterial effect against $A$. cavieae (5-8), A. hydrophila (6-7mm), L. garvieae (5-7mm). However, effect on immune response and disease resistance against Vibrio anguillarum, A. sobria and P. aeroginosa of essential oil of M. suaveolens should be investigated in vivo in cultured fish species in future studies.

Table II. Antimicrobial activities of $M$. suaveolence essential oil against fish pathogen bacteria (inhibition zone, $\mathrm{mm}$ ).

\begin{tabular}{|c|c|c|c|c|c|c|}
\hline Pathogens & \multicolumn{7}{|c|}{ Concentrations $\left(\boldsymbol{\gamma} \mathbf{L ~ m L}^{-1}\right)$} \\
\hline & $\mathbf{1 0 0 0}$ & $\mathbf{5 0 0}$ & $\mathbf{2 5 0}$ & $\mathbf{1 2 5}$ & $\mathbf{6 2 . 5}$ & $\mathbf{3 1 . 2 5}$ \\
\hline V. anguillarum & 50 & 40 & 30 & 11 & 14 & 10 \\
\hline P. aeroginosa & 6 & 13 & 9 & 17 & 16 & 20 \\
\hline A. sobria & 18 & 15 & 12 & 10 & 8 & 6 \\
\hline E. tarda & 13 & 15 & 13 & 11 & 10 & 8 \\
\hline Y. ruckeri & 9 & 12 & 12 & 10 & 6 & 6 \\
\hline S. warneri & 10 & 10 & 9 & 9 & - & - \\
\hline V. salmoninarum & 7 & 9 & 9 & 7 & 7 & 6 \\
\hline Staphylococcus sp. & 8 & 9 & 8 & 6 & 6 & - \\
\hline A. cavieae & 5 & 7 & 8 & 8 & 6 & 7 \\
\hline A. hydrophila & 7 & 7 & 7 & 6 & - & - \\
\hline L. garvieae & 5 & 7 & 7 & 6 & 6 & 6 \\
\hline
\end{tabular}




\section{REFERENCES}

ABUTBUL S, GOLAN-GOLDHIRSH A, BARAZANI O, OFIR R \& ZILBERG D. 2005. Screening of desert plants for use against bacterial pathogens in fish. Isr J Aquacult/Bamid 57(2): 71-80.

ADEL M, SAFARI R, GHITANCHI AH \& ZORRIEHZAHRA MJ. 2016. Chemical composition and in vitro antimicrobial activity of some Iranian medical herbs against Yersinia ruckeri. Iran J Fish Sci 15(3): 1108-1123.

AL LAHAM SA \& AL FADEL FM. 2014. Antibacterial activity of various plants extracts against antibiotic-resistant Aeromonas hydrophila. Jundishapur J Microbiol 7(7): 1-7.

ANDREWS JM. 2004. BSAC standardized disc susceptibility testing method (version 3). J Antimicrob Chemother 53(5): 713-728.

BANSEMIR A, BLUME M, SCHRÖDER S \& LINDEQUIST U. 2006. Screening of cultivated seaweeds for antibacterial activity against fish pathogenic bacteria. Aquacult 252: 79-84.

BAYDAR H, SAĞDiç O, ÖZKAN G \& KARADOĞAN T. 2004. Antibacterial activity and composition of essential oils from Origanum, Thymbra and Satureja species with commercial importance in Turkey. Food Control 15(3): 169-172.

BIRINCI YILDIRIM A \& TURKER H. 2018. Antibacterial activity of some aromatic plant essential oils against fish pathogenic bacteria. J Limnol Freshw Fisheries Res 4(2): 67-74.

BOŽOVIĆ M, PIROLLI A \& RAGNO R. 2015. Mentha suaveolens Ehrh.(Lamiaceae) essential oil and its main constituent piperitenone oxide: biological activities and chemistry. Molecules 20(5): 8605-8633.

CHAUHAN SS \& AGARWAL R. 2013. Evaluation of antibacterial activity of volatile oil from Mentha spicata L. J Drug Deliv Ther 3(4): 120-121.

CITARASU T. 2010. Herbal biomedicines: a new opportunity for aquaculture industry. Aquacult Int 18(3): 403-414.

DILER O, GORMEZ O, DILER I \& METIN S. 2017. Effect of oregano (Origanum onites L.) essential oil on growth, lysozyme and antioxidant activity and resistance against Lactacoccus garvieae in rainbow trout, Oncorhynchus mykiss (Walbaum). Aquacult Nutr 23: 844-851.
EKICI S, DILER O, DIDINEN BI \& KUBILAY A. 2011. Antibacterial activity of essential oils from medicinal plants against bacterial fish pathogens. Kafkas Univ Vet Fak Derg 17: 47-54.

EL-KASHOURY ESA, EL-ASKARY HI, KANDIL ZA, EZZAT SM, SALEM MA \& SLEEM AA. 2014. Chemical and biological study of Mentha suaveolens Ehrh. cultivated in Egypt. J Med Plant Res 8(20): 747-755.

HANIFFA MA \& KAVITHA K. 2012. Antibacterial activity of medicinal herbs against the fish pathogen Aeromonas hydrophila. J Agr Tech 8(1): 205-211.

KUMAR P, MISHRA S, MALIK A \& SATYA S. 2011. Insecticidal properties of Mentha species: a review. Ind Crops Prod 34(1): 802-817.

METIN S, DIDINEN BI, MERCIMEK EB \& ERSOY AT. 2017. Antibacterial activity of some essential plant oils againts some bacterial fish pathogens. Aquacult Stud 17(1): 59-69.

MORENO L, BELLO R, PRIMO-YúfERA E \& ESPLUGUES J. 2002. Pharmacological properties of the methanol extract from Mentha suaveolens Ehrh. Phytother Res 16(S1): 10-13.

ONTAS C, BABA E, ERCAN MD, KAPLANER E, KUÇUKAYDIN S \& OZTURK M. 2016. Antibacterial activity of Citrus limon peel essential oil and Argania spinosa oil against fish pathogenic bacteria. Kafkas Univ Vet Fak Derg 22(5): 741-749.

OUMZIL H, GHOULAMI S, RHAJAOUI M, ILIDRISSI A, FKIH-TETOUANI S, FAID M \& BENJOUAD A. 2002. Antibacterial and antifungal activity of essential oils of Mentha suaveolens. Phytother Res 16(8): 727-731.

SCHNICK RA, ALDERMAN DJ, ARMSTRONG R, LE GOUVELLO R, ISHIHARA S, LACIERDA EC, PERCIVAL S \& ROTH M. 1997. World wide aquaculture drug and vaccine registration progress. Bull Eur Assoc Fish Pathol 17(6): 251-260.

SUTOUR S, BRADESI P, DE ROCCA-SERRA D, CASANOVA J \& TOMI F. 2008. Chemical composition and antibacterial activity of the essential oil from Mentha suaveolens ssp. insularis (Req.) Greuter. Flavour Frag J 23(2): 107-114.

TURKER H \& YILDIRIM AB. 2015. Screening for antibacterial activity of some Turkish plants against fish pathogens: a possible alternative in the treatment of bacterial infections. Biotechnol Biotech Eq 29(2): 281-288. 


\section{How to cite}

METIN S, DIDINEN BI, TELCI I \& DILER O. 2021. Essential oil of Mentha suaveolens Ehrh., composition and antibacterial activity against bacterial fish pathogens. An Acad Bras Cienc 93: e20190478. DOI 10.1590/0001-3765202120190478.

Manuscript received on April 24, 2019;

accepted for publication on July 2, 2019

\section{SECIL METIN ${ }^{1}$}

https://orcid.org/0000-0002-8029-5624

\section{BEHIRE I. DIDINEN}

https://orcid.org/0000-0003-2628-1480

\section{ISA TELCl ${ }^{2}$}

https://orcid.org/0000-0002-3651-1641

\section{OZNUR DILER}

https://orcid.org/0000-0003-0330-3448

${ }^{1}$ Isparta University of Applied Sciences, Faculty of Eğirdir

Fisheries, Department of Aquaculture, Isparta 32260, Turkey

${ }^{2}$ Isparta University of Applied Sciences, Faculty of Agriculture, Department of Field Crops, Isparta 32260, Turkey

Correspondence to: Behire Ișıl Didinen

E-mail:behiredidinen@hotmail.com

\section{Author contributions}

SM, BID, IT and OD participated in the planning of the study, in vitro antibacterial assays and drafting the manuscript. All authors read and approved the final manuscript.

\section{(cc) BY}

